\title{
Interaction of Adenosine and Acetylcholine on the Bullfrog Atrium
}

\author{
Masayosi Goto, Mami Urata, Atsuko Yatani, \\ and Takao Fujino \\ Department of Physiology, Faculty of Medicine, \\ Kyushu University, Fukuoka, 812 Japan
}

\begin{abstract}
As adenosine has a potent stabilizing action on catecholamine stimulation in the myocardium, the mode of interaction of adenosine and acetylcholine ( $\mathrm{ACh}$ ) was studied with regard to the membrane potential, current and tension components of the bullfrog atrium, using the single or double-sucrose gap method. Adenosine $\left(10^{-4}-3 \times 10^{-3} \mathrm{M}\right)$ augmented the twitch contraction in the presence of ACh $\left(10^{-9}-5 \times 10^{-7} \mathrm{M}\right)$ by lengthening the duration of the action potential. The dose-tension response curve for $\mathrm{ACh}$ was modified by adenosine, producing a rise of the inhibitory threshold of $\mathrm{ACh}$, and the modification showed a non competitive interaction of these compounds. Under the voltage clamp, ACh-induced steady current $\left(I_{\mathrm{ACh}}\right)$ was inhibited by adenosine noncompetitively. The known inhibition of slow inward current $\left(I_{\mathrm{s}}\right)$ by ACh was enhanced by adenosine, while the delayed outward current $\left(I_{x}\right)$ was markedly suppressed. $I_{\mathrm{s}}$-dependent and -independent tension components were both inhibited by adenosine, thereby suggesting a decrease in intracellular concentrations of calcium. The potent suppression of $I_{\mathrm{ACh}}$ and $I_{\mathrm{x}}$ induced by adenosine, however, appeared to mitigate the inhibitory action of $\mathrm{ACh}$ on the action potential and twitch contraction.
\end{abstract}

Since the first report by DruRy and Szent-GyörgYI (1929), the inhibitory actions of adenine compounds on the heart have been well investigated (see Drummond and Severson, 1979; Burnstock, 1980). These studies have shown that adenosine and adenine nucleotides have an overall effect similar to that of acetylcholine $(\mathrm{ACh})$ by slowing and weakening the heartbeat. In the mammalian atrium, the depression of contraction with adenosine is accompanied by a shortening of the action potential, possibly due to an increased potassium permeability (Johnson and McKinnon, 1956; Hollander and WebB, 1957), and in the frog sinus venosus, adenosine and related compounds produce a marked hyperpolarization presumably reflecting an increase in potassium conductance (HARTZELL, 1979). SCHRADER et al. (1975) and Belardinelli et al. (1979), however, reported

Received for publication November 25, 1980

後藤昌義, 浦田百美, 八谷アッ子, 藤野孝雄 
that in guinea-pig and rat atria, adenosine is a potent inhibitor of the catecholamine-induced slow action potential and they suggested a possible inhibitory action on calcium influx. Gото et al. $(1977,1978,1979)$ examined the effects of adenine compounds on the bullfrog atrium under voltage clamp and found that energy-poor nucleotides and adenosine inhibited the slow inward current and the phasic and tonic tension components.

Thus, the actions of adenosine seem to resemble those of ACh which is known to increase the potassium permeability (TRAUTWEIN et al., 1956; HUTTER, 1961; GARNIER et al., 1978) and to reduce the slow inward current (Iкемото and Goto, 1975, 1977; GILES and NoBLE, 1976). In the present study which deals with possible additive or antagonistic interactions of the effects of $\mathrm{ACh}$ and adenosine on the bullfrog atrium, we attempt to clarify the role of adenosine in the cholinergic action on the myocardium in contrast to the potent stabilizing action of adenosine on catecholamine stimulation (SCHRADER et al., 1975, 1977; Gото et al., 1978).

\section{METHODS}

Preparation and experimental apparatus were the same as reported previously (Goто et al., 1978, 1979). In brief, thin muscle bundles $(0.4-0.5 \mathrm{~mm}$ in diameter and 5-6 $\mathrm{mm}$ in length) were isolated from the left atrium of the bullfrog, Rana catesbeiana, and by means of a conventional double sucrose-gap method, the membrane potential, current, and tension of the muscle were measured simultaneously under voltage clamped and unclamped conditions.

Cumulative dose-tension response curves for $\mathrm{ACh}$ with or without adenosine (RESUlTs 1) were determined using the single gap method (YATANI et al., 1978). For these tests, the right side sucrose-gap was omitted by removing the rubber membranes, and the large terminal compartment was used as the test chamber.

ACh-induced extra current $\left(I_{\mathrm{ACh}}\right)$ was measured by the method of GARNIER et al. (1978), as described in the text (RESULTS 3), and the voltage dependency of $I_{\mathrm{ACh}}$ was estimated from the difference in the terminal current level of the voltagecurrent relationships obtained with $2.0 \mathrm{sec}$ pulses before and after application of $\mathrm{ACh}$.

All experiments were performed after an equilibration time of over $60 \mathrm{~min}$ in normal Ringer's solution and at a constant temperature of $17 \pm 0.5^{\circ} \mathrm{C}$.

\section{RESULTS}

1. Effects of adenosine on the dose-tension response curve for ACh

To examine the general mode of interaction between adenosine and $\mathrm{ACh}$ on the tension response, dose-tension response curves for $\mathrm{ACh}$ were first determined in the presence and absence of adenosine $\left(10^{-4}-3 \times 10^{-3} \mathrm{M}\right)$. Figure 1 shows the results of cumulative dose-response relations in the bullfrog atrium. ACh pro- 


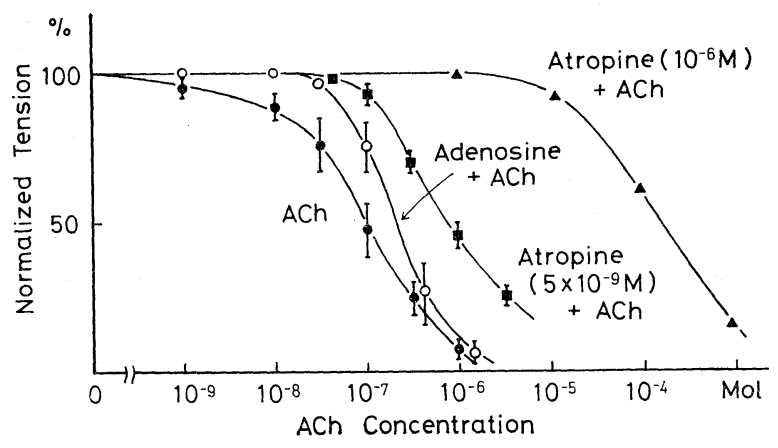

Fig. 1. Cumulative dose-tension response curve for $\mathrm{ACh}(\bullet)$, and the curves modified in the presence of atropine $\left(\boldsymbol{\square}, 5 \times 10^{-9} \mathrm{M} ; \mathbf{\Delta}, 10^{-6} \mathrm{M}\right)$ or adenosine $\left(O, 3 \times 10^{-3} \mathrm{M}\right)$. Values are means of five experiments $(n=5-3)$ with or without standard error. Note a non-competitive inhibition by adenosine of the depressive effects of ACh in comparison with a competitive inhibition by atropine.

duced a dose-dependent inhibition of the twitch contraction, showing a halfmaximal inhibition $\left(\mathrm{p} D_{2}\right)$ at about $7 \times 10^{-8} \mathrm{M}$ with a threshold at around $10^{-9} \mathrm{M}$. The contraction all but disappeared with concentrations of ACh over $10^{-6} \mathrm{M}$.

In the presence of adenosine $\left(3 \times 10^{-3} \mathrm{M}\right)$, the dose-tension response curve for ACh was modified, showing a higher threshold of inhibition $\left(3 \times 10^{-8} \mathrm{M}\right)$ and a steep fall of twitch tension with increases in the concentration of ACh. Thus, a significant increase in tension by addition of adenosine was observed when the concentrations of $\mathrm{ACh}$ were between $10^{-9}-10^{-7} \mathrm{M}$, suggesting an antagonistic action between ACh and adenosine. The mode of antagonistic action differed from that seen with atropine which produced a typical parallel shift of the dose-response curve. The interaction between $\mathrm{ACh}$ and adenosine appeared to be non-competitive.

Figure 2 shows an example of the interaction between the effects of $\mathrm{ACh}$ and adenosine on the membrane potential and twitch contraction. The sole action of adenosine was a slight depolarization of the membrane and a prolongation of the action potential accompanied by a suppression of twitch contraction (Gото et al., 1978). In the presence of $\mathrm{ACh}\left(10^{-8}-10^{-7}\right)$, however, the addition of adenosine $\left(3 \times 10^{-3} \mathrm{M}\right)$ produced a considerable prolongation of the action potential and an augmentation of the twitch tension (Fig. 2A). Adenosine $10^{-4} \mathrm{M}$ produced similar effects (Fig. 2B). Neither the resting gap potential nor the overshoot of gap action potential changed appreciably. Thus, when application and removal of adenosine were repeated in the constant presence of $\mathrm{ACh}$, the tension response always appeared to be larger during the period of application.

2. Effects of adenosine in the presence of ACh on the membrane currents and tension components

In the myocardium, $\mathrm{ACh}$ induces, 1) an increase in $\mathrm{K}$ permeability (TrAU- 


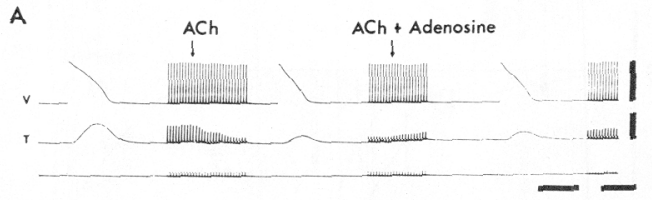

B

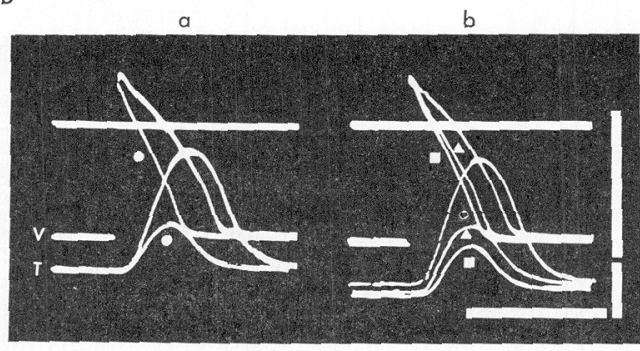

Fig. 2. Interaction between the effects of ACh and adenosine on the membrane potential $(V)$ and contractile tension $(T)$. A) $\mathrm{ACh}\left(5 \times 10^{-8}\right)$ produced a shortening of action potential and a decrease of contractile tension. Addition of adenosine $\left(3 \times 10^{-3} \mathrm{M}\right)$ in the presence of ACh elicited a prolongation of action potential and an enhancement of contraction. B) Similar data with a lower concentration of adenosine. a, superimposed records of control and response $4 \mathrm{~min}$ after $\mathrm{ACh}\left(5 \times 10^{-8} \mathrm{M}, \mathbf{0}\right)$; b, those of $2 \mathrm{~min}$ (1) and $5 \mathrm{~min}$ (A) after addition of adenosine $\left(10^{-4} \mathrm{M}\right)$, and $15 \mathrm{~min}$ after washing with normal Ringer. Vertical bars are calibrations of $100 \mathrm{mV}$, and $0.02 \mathrm{~g}$ for voltage and tension, respectively. Horizontal bars are time calibrations of $1.0 \mathrm{sec}$ and $1 \mathrm{~min}$ for $\mathrm{A}$, and $1.0 \mathrm{sec}$ for $\mathrm{B}$.
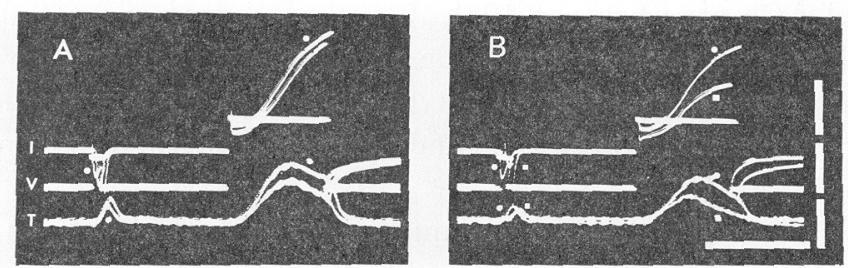

Fig. 3. Effects of $\mathrm{ACh}$, and $\mathrm{ACh}$ plus adenosine on the membrane currents and tension components. A) Control responses to small $(60 \mathrm{mV}, 0.2 \mathrm{sec})$ and large depolarizing pulses $(140 \mathrm{mV}, 2.0 \mathrm{sec})$ and responses $4 \mathrm{~min}$ after $\mathrm{ACh}\left(5 \times 10^{-8}\right.$, white dots $)$ are superimposed. B) Similar superimposed records of responses in the presence of $\mathrm{ACh}$ (white dots) and those $5 \mathrm{~min}$ after further addition of adenosine $\left(3 \times 10^{-3} \mathrm{M}\right.$, white squares). Vertical bars from the top to the bottom are calibrations of $2 \mu \mathrm{A}, 100 \mathrm{mV}$ and $0.1 \mathrm{~g}$ for membrane current $(I)$, voltage $(V)$ and tension $(T)$, respectively. Horizontal bar marks time, 2 sec.

TWEIN et al., 1956; HUTTER, 1961), 2) a decrease of the slow inward current $\left(I_{\mathrm{s}}\right)$ (Iкемото and Goto, 1975; Giles and Noble, 1976; Garnier et al., 1978), and 3) an inhibition of $I_{\mathrm{s}}$-dependent phasic tension and an augmentation of $I_{\mathrm{s}}$-independent tonic tension (Iкемото and Gото, 1975). Most of these effects were confirmed in the present experiment. Figure $3 \mathrm{~A}$ shows the effects of $\mathrm{ACh}$ on the $I_{\mathrm{s}}$-dependent and -independent tension responses to small $(60 \mathrm{mV}, 0.2 \mathrm{sec})$ and large $(140 \mathrm{mV}$, 
$2.0 \mathrm{sec})$ depolarizing pulses in the constant presence of $\operatorname{TTX}\left(1.5 \times 10^{-6} \mathrm{M}\right)$, respectively, in which $I_{\mathrm{s}}$ became nearly maximum in the former and negligible in the latter. $\mathrm{ACh}\left(5 \times 10^{-8} \mathrm{M}\right.$, white dots $)$ inhibited the $I_{\mathrm{s}}$ and $I_{\mathrm{s}}$-dependent tension and augmented the $I_{\mathrm{s}}$-independent tension. When adenosine $\left(3 \times 10^{-3} \mathrm{M}\right)$ was added in the presence of ACh (Fig. 3B), the $I_{\mathrm{s}}$ and $I_{\mathrm{s}}$-dependent tension for small pulses were further diminished and the outward current as well as the $I_{\mathrm{s}}$-independent tension for large pulses was markedly inhibited. The inhibition of the outward current appeared both in the instantaneous and time-dependent current components.

Next, the membrane current-voltage relation were examined to assess in detail the mode of interference. Figure $4 \mathrm{~A}$ shows the effects of $\mathrm{ACh}$, and $4 \mathrm{~B}$, those of adenosine in the presence of ACh. TTX $\left(1.5 \times 10^{-6} \mathrm{M}\right)$ was constantly present in the bathing solution. ACh $\left(5 \times 10^{-7} \mathrm{M}\right)$ inhibited the $I_{\mathrm{s}}$, produced a so-called ACh extra current $\left(I_{\mathrm{ACh}}\right.$, GARNIER et al., 1978) and increased the amplitude of terminal currents for hyperpolarizing and depolarizing pulses (Fig. 4A). When adenosine $\left(3 \times 10^{-3} \mathrm{M}\right)$ was added in the presence of ACh (Fig. 4B), there was a marked depression of the terminal current levels and the $I_{\mathrm{s}}$ diminished further. The depression of the terminal current, however, was more conspicuous with stronger

A

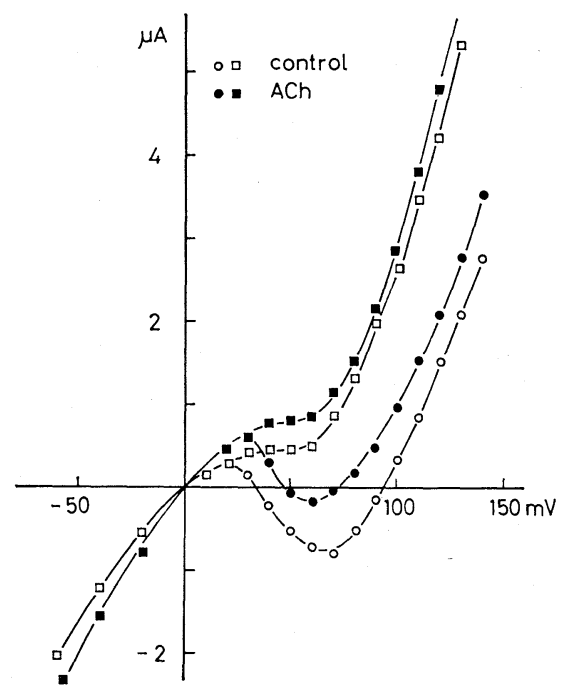

B

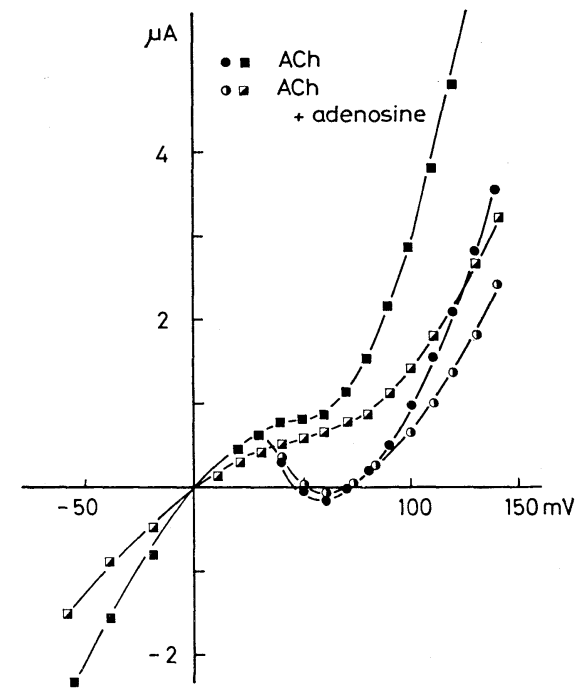

Fig. 4. Current-voltage relations in TTX Ringer, and effects of ACh and ACh plus adenosine on the membrane currents. A) The relationships before $(O, \square)$ and 8-14 min after ACh $\left(5 \times 10^{-7} \mathrm{M}, \bullet, \mathbf{\square}\right)$. B) Those with $\mathrm{ACh}(\boldsymbol{\bullet}, \mathbf{E})$ and 10-15 min after addition of adenosine $\left(3 \times 10^{-3} \mathrm{M}, \boldsymbol{\square}, \boldsymbol{\square}\right)$. Circles denote peak value of inwardly directed current, and squares, terminal current levels at the end of $2.0 \mathrm{sec}$ pulses. Note the appearance of ACh-induced extra current $\left(I_{\mathrm{ACh}}\right)$ and a decrease of $I_{\mathrm{s}}$ in Fig. A, and a marked inhibition of $I_{\mathrm{ACh}}, I_{\mathrm{s}}, I_{\mathrm{x}}$ by further addition of adenosine in Fig. B. 
pulses of depolarization, suggesting that the effect was not due only to the elimination of the $I_{\mathrm{ACh}}$ which shows an anomalous rectification (GARNIER et al., 1978; Noma and Trautwein, 1978; Noma et al., 1979), but was largely caused by an inhibition of the delayed outward current $\left(I_{\mathrm{x}}\right)$. These results indicate that the prolongation of the action potential and the partial recovery of tension after adenosine in the presence of ACh are mainly due to a potent inhibition of these outward currents $\left(I_{\mathrm{ACh}}, I_{\mathrm{x}}\right)$.

\section{Antagonistic effects of adenosine on the ACh-induced extra current}

Since the antagonistic interaction between adenosine and ACh mainly occurred in the terminal current levels, the interaction was examined on the isolated AChinduced extra current $\left(I_{\mathrm{ACh}}\right)$. The $I_{\mathrm{ACh}}$ was measured following the method of GARNIER et al. (1978). The experimental protocol is shown in Fig. 5A; i. e., the membrane was maintained at a given depolarized potential $(+50$ or $+60 \mathrm{mV}$ from the resting potential) and $\mathrm{ACh}$ was introduced in steps of log-unit concentrations, at 5 min intervals. ACh produced an outward current which reached a maximum value corresponding to the concentration in $1 \mathrm{~min}$, and the total amount of $I_{\mathrm{ACh}}$ extra current increased with additional concentration of $\mathrm{ACh}$. After the addition of adenosine $\left(10^{-3} \mathrm{M}\right)$, however, $I_{\mathrm{ACh}}$ extra current was markedly inhibited, as shown in Fig. 5B.

The results of these and similar experiments were plotted as dose- $I_{\mathrm{ACh}}$ response curves in Fig. 5C. The $I_{\mathrm{ACh}}$ appeared with a threshold of $10^{-7} \mathrm{M}$ or less, increased dose-dependently and became saturated at around $10^{-4} \mathrm{M}$. p $D_{2}$ was about $2 \times 10^{-6} \mathrm{M}$. After the addition of adenosine $\left(10^{-3} \mathrm{M}\right)$, the $I_{\mathrm{ACh}}$ was strongly inhibited, but the inhibition of the maximal response was greater in the case of $+60 \mathrm{mV}$ depolarization than that of $+50 \mathrm{mV}$, thereby suggesting anomalous characteristics of the background current. The threshold and relative dose-dependency were not appreciably altered. Higher concentrations of adenosine $\left(3 \times 10^{-3} \mathrm{M}\right)$ eliminated the $I_{\mathrm{ACh}}$ (figure not shown). The dose-dependent effects of adenosine indicate that the interaction between $\mathrm{ACh}$ and adenosine on $I_{\mathrm{ACh}}$ is noncompetitive.

\section{Action of adenosine in the presence of a low concentration of acetylcholine}

Adenosine produced non-competitive inhibition of $I_{\mathrm{ACh}}$. This inhibition, however, would hardly explain the modification of the dose-response curve due to adenosine (see Fig. 1), because with the application of adenosine, the tension was recovered when the concentrations of $\mathrm{ACh}$ were below $10^{-7} \mathrm{M}$ where $I_{\mathrm{ACh}}$, and hence, the inhibition of $I_{\mathrm{ACh}}$ by adenosine, were rarely observed (Fig. 5C).

Another explanation for the modification may be the recovery of the $I_{\mathrm{s}}$ due to adenosine which heretofore had been inhibited by ACh. The possibility was examined on $I_{\mathrm{s}}$ isolated in Ringer solution containing TTX $\left(1.5 \times 10^{-6} \mathrm{M}\right)$, but such was not the case. Figure $6 \mathrm{~A}$ shows the effects of $\mathrm{ACh}\left(5 \times 10^{-8} \mathrm{M}\right)$ on the voltage- 

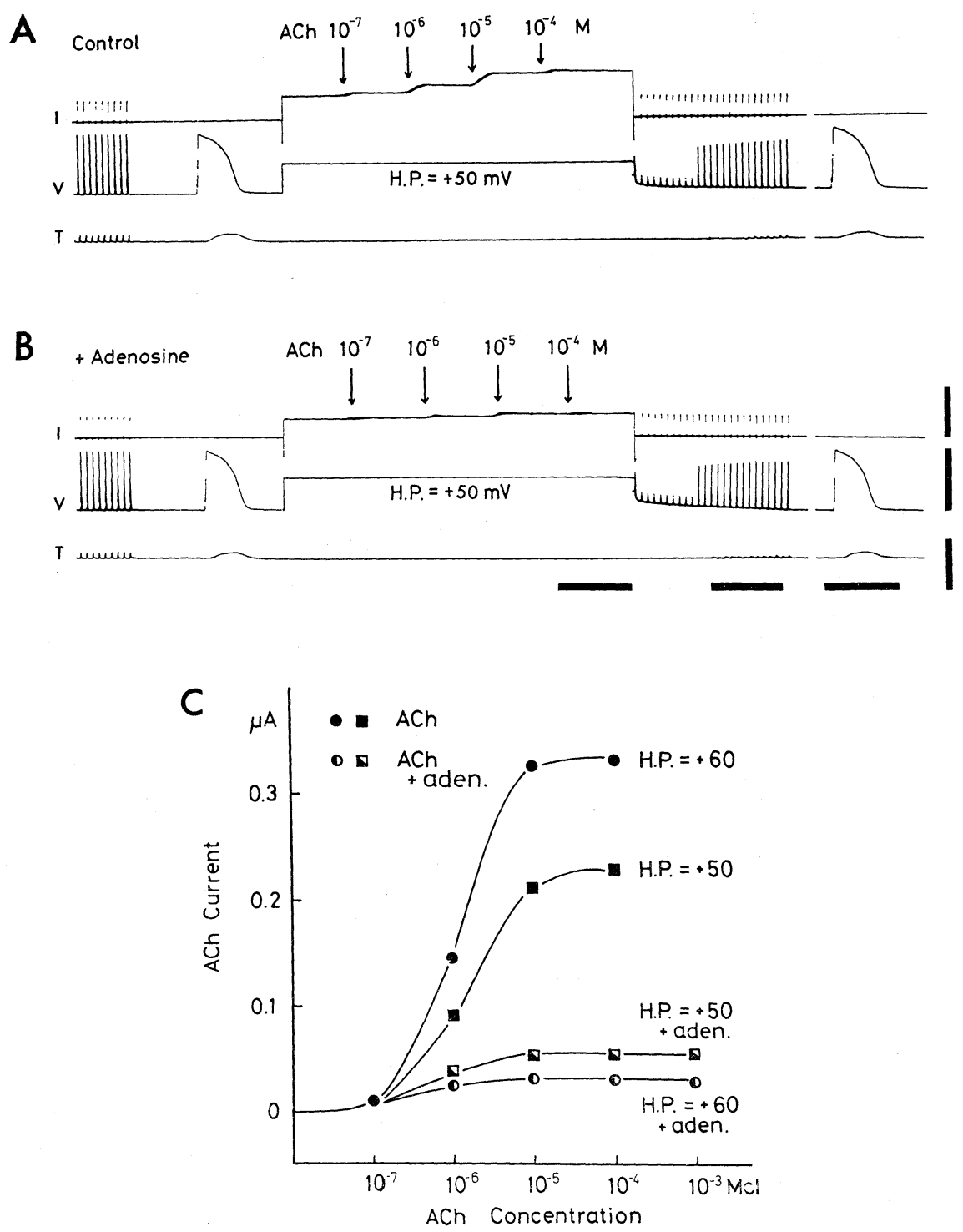

Fig. 5. Isolated $I_{\mathrm{ACh}}$ and effect of adenosine. The membrane potential was held at a depolarized level of $50 \mathrm{mV}$, and ACh was introduced cumulatively in steps of log-unit concentration. A) $I_{\mathrm{ACh}}$ in control condition. B) Depression of $I_{\mathrm{ACh}}$ in the presence of adenosine $\left(10^{-3} \mathrm{M}\right)$. Vertical bars from the top to the bottom are calibration of $0.5 \mu \mathrm{A}$, $100 \mathrm{mV}$ and $0.2 \mathrm{~g}$ for current $(I)$, voltage $(V)$ and tension $(T)$. Horizontal bars are time calibrations of $5 \mathrm{~min}, 2 \mathrm{~min}$ and $1 \mathrm{sec}$ for the slow, middle and fast records, respectively. C) Dose- $I_{\mathrm{ACh}}$ response curves in control conditions $(\boldsymbol{\bullet}, \mathbf{\square})$ and the effects of adenosine $\left(10^{-3} \mathrm{M}, \boldsymbol{\top}, \mathbf{\nabla}\right)$. Squares are data at $50 \mathrm{mV}$ depolarization (H. P.) and circles, at $60 \mathrm{mV}$. Adenosine markedly inhibited $I_{\mathrm{ACh}}$.

Vol. 31, No. 4, 1981 
A

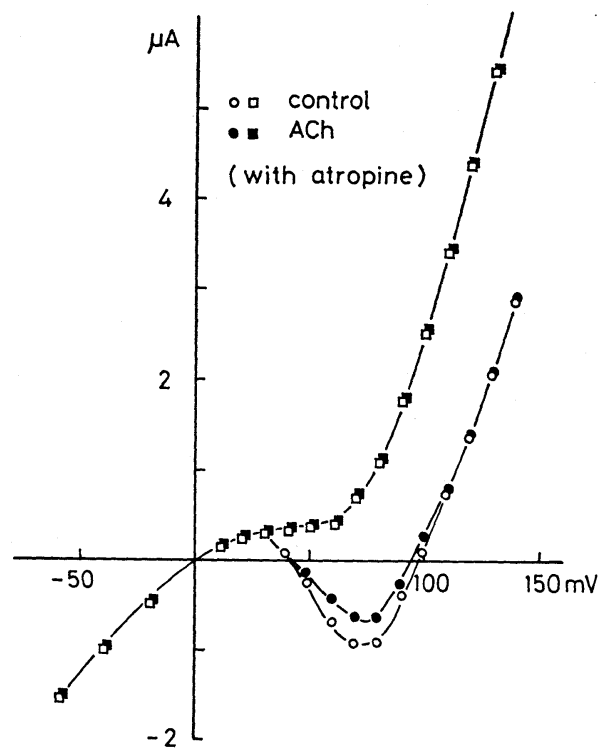

B

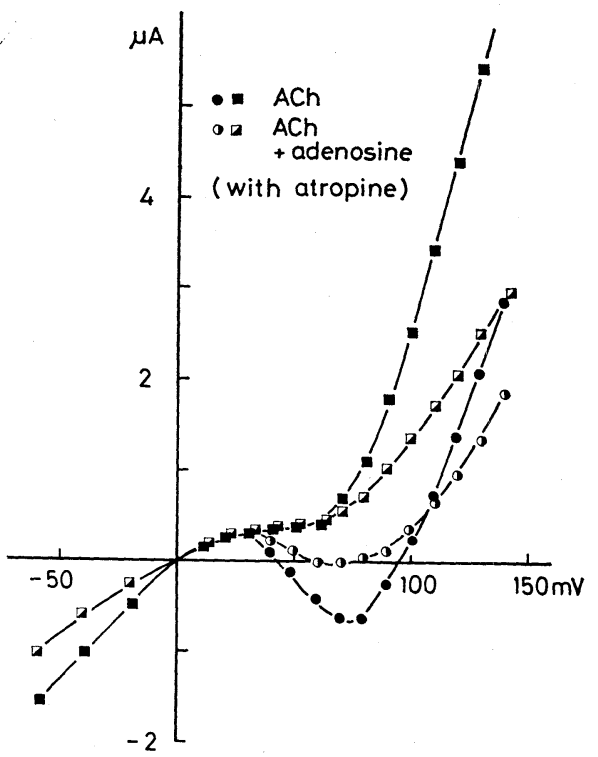

Fig. 6. Effects of low concentration of $\mathrm{ACh}\left(5 \times 10^{-8} \mathrm{M}\right)$ and that plus adenosine $\left(3 \times 10^{-3} \mathrm{M}\right)$ on the current-voltage relationships in the presence of TTX $\left(1.5 \times 10^{-6} \mathrm{M}\right)$ and atropine $\left(10^{-9} \mathrm{M}\right)$. A) Relationships before $(O, \square)$ and $9-15 \mathrm{~min}$ after ACh $(\bullet, \square)$. B) Those after ACh $(\bullet, \boldsymbol{\square})$ and 8-15 min after addition of adenosine $(\boldsymbol{\bullet}, \boldsymbol{\square})$. Circles denote peak values of inwardly directed current and squares, terminal current levels at the end of 2.0 sec pulses. Note absence of $I_{\mathrm{ACh}}$ in $\mathrm{A}$, and marked depression of $I_{\mathrm{s}}$ and $I_{\mathrm{x}}$ in $\mathrm{B}$.

current relationship in the constant presence of TTX and atropine $\left(10^{-9} \mathrm{M}\right)$, and Fig. 6B, modification of the effects after further addition of adenosine $\left(3 \times 10^{-3} \mathrm{M}\right)$. The low concentration of atropine was always used in order to eliminate endogenous release of ACh, particularly when the effects of low concentrations of ACh were examined. ACh with atropine in these concentrations did not elicit $I_{\mathrm{ACh}}$, but did produce a distinct inhibition of $I_{\mathrm{s}}$ (Fig. 6A). Moreover, the inhibition was further enhanced after the addition of adenosine (Fig. 6B). The enhancement of inhibition was also observed with a higher concentration of ACh $\left(5 \times 10^{-7} \mathrm{M}\right)$ (Fig. 4B). These results clearly ruled out the possibility of a recovery by adenosine of the inhibited $I_{\mathrm{s}}$ due to ACh.

On the other hand, it should be noted that the delayed outward current as well as the background current for hyperpolarization were markedly inhibited by the addition of adenosine (Fig. 6B). When the tail of the outward current $\left(I_{\mathrm{x}}\right)$ was isolated with long double step clamp pulses (Fig. 7A) and when the effects of ACh and adenosine on the maximally activated tail current of $I_{x}$ were examined, we found that $\mathrm{ACh}\left(10^{-7}-10^{-5} \mathrm{M}\right)$ reduced the outward current tail, and that the addition of 


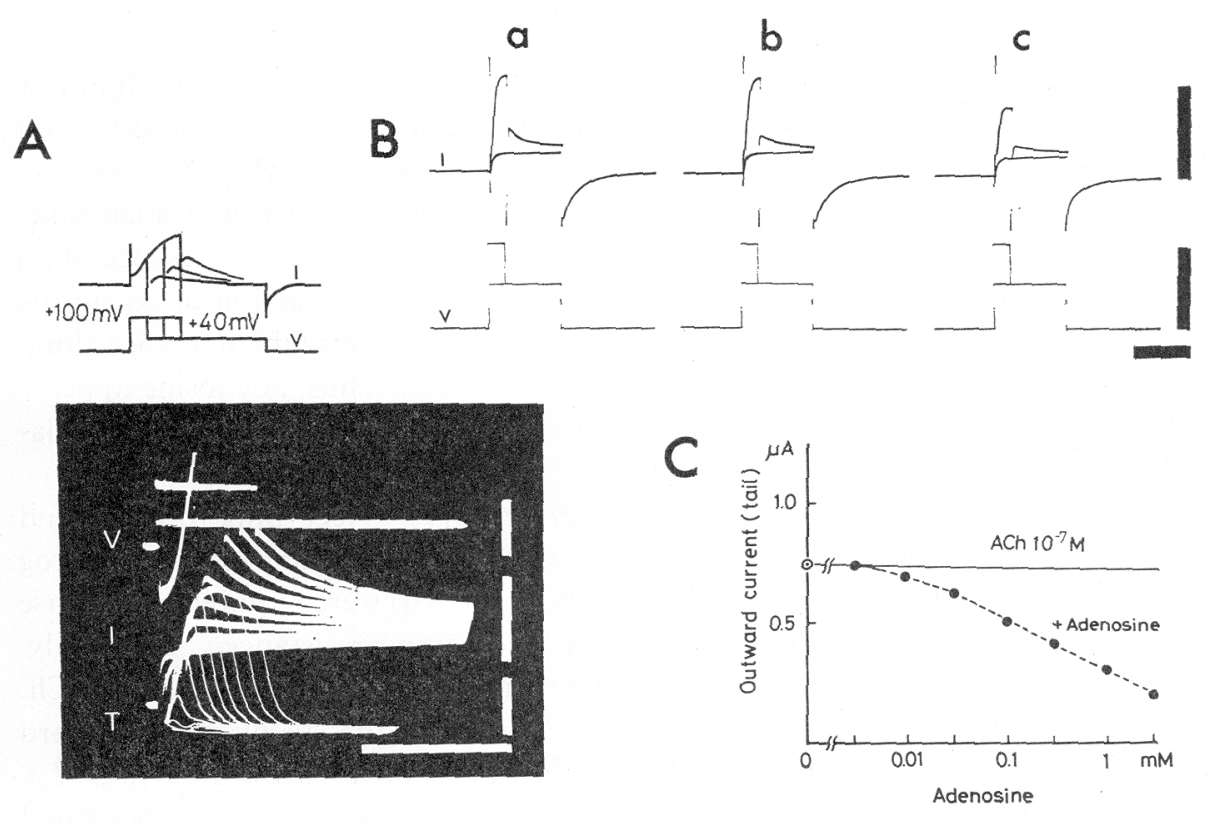

Fig. 7. Effects of ACh and addition of adenosine on delayed outward current. A) Activation of delayed outward current. Grade of activation was observed on the tail current. Two step clamp pulses were used. 1st step pulses were depolarizations of $100 \mathrm{mV}$ and of different durations $(0-3 \mathrm{sec})$ from holding potential of $-80 \mathrm{mV}$, and 2 nd step pulses, constant depolarization of $50 \mathrm{mV}$ and $10 \mathrm{sec}$. 'The maximal activation of tail current was obtained by 1 st step pulse of $3.0 \mathrm{sec}$. B) The effects of ACh and adenosine on the maximally activated tail current. Amplitude of the tail current is estimated by the difference of the currents with or without 1 st step pulse of $100 \mathrm{mV}$ and $3 \mathrm{sec}$. a, control; b, $5 \mathrm{~min}$ after $\mathrm{ACh}\left(10^{-7} \mathrm{M}\right)$ and $\mathrm{c}, 5 \mathrm{~min}$ after addition of adenosine $\left(10^{-3} \mathrm{M}\right)$. Note depression of delayed outward current during and after 1st step depolarization by ACh and further by addition of adenosine. In Fig. A, vertical bars from the top to the bottom are calibrations of $100 \mathrm{mV}, 1 \mu \mathrm{A}$ and $0.02 \mathrm{~g}$ for membrane voltage $(V)$, current $(I)$, and tension $(T)$, respectively. In Fig. B, calibrations of membrane current, $5 \mu \mathrm{A}$, and voltage, $100 \mathrm{mV}$. Horizontal bars denote $5 \mathrm{sec}$ in Fig. A and $10 \mathrm{sec}$ in Fig. B. C) Dose-dependent inhibition of isolated delayed outward current by adenosine in the presence (-) of ACh $\left(10^{-7} \mathrm{M}\right)$. Peak tail current after the 1 st pulse was plotted against adenosine concentration.

adenosine further enhanced the depression (Fig. 7B). Reduction of the tail current due to $\mathrm{ACh}$, however, did not necessarily indicate a depression of $I_{\mathrm{x}}$ since potassium accumulates under the action of ACh (GARNIER et al., 1978) with even the possibility of relaxation of $I_{\mathrm{ACh}}$ (DIFRANCESCO et al., 1980), although the threshold concentration for $I_{\mathrm{ACh}}$ was used in this case. The apparent depression due to further addition of adenosine is of significance, because if $I_{\mathrm{ACh}}$ was present the tail current would be enhanced via inhibition of $I_{\mathrm{ACh}}$ by adenosine. Thus, adenosine depresses the $I_{\mathrm{x}}$ in the presence of $\mathrm{ACh}$, and such could be observed with adenosine in doses as low as $10^{-5} \mathrm{M}$ (Fig, 7C). 


\section{DISCUSSION}

In the bullfrog atrium, the twitch tension which was depressed by ACh in low concentrations was recovered by the application of adenosine. The dose-tension response curves for $\mathrm{ACh}$ (Fig. 1) and dose- $I_{\mathrm{ACh}}$ response curves (Fig. 5C) both revealed the presence of non-competitive interaction between $\mathrm{ACh}$ and adenosine. Although the nature of these interactions was not fully clarified, the presence of an antagonistic interaction contrasted with the potent stabilizing action of adenosine on catecholamine stimulation in both mammalian and amphibian myocardium (SCHRADER et al., 1975, 1977; Goto et al., 1978, 1979). Thus, adenosine appears as a stabilizing agent not only for catecholamines but also for cholinergic stimulation.

The slow inward current $\left(I_{\mathrm{s}}\right)$ and ACh current $\left(I_{\mathrm{ACh}}\right)$. According to GLIES and Noble (1976), ACh in concentrations over $2.0 \times 10^{-8} \mathrm{M}$ reduced $I_{\mathrm{s}}$ in the bullfrog atrium, while relatively high doses of ACh (above $10^{-7} \mathrm{M}$ ) were required to increase the potassium permeability and decrease the membrane resistance. Contrarily, TEN EICK et al. (1976) reported that in mammalian atria, the concentration of ACh, which reduced the twitch tension to $30-40 \%$, increased the steady-state outward current $\left(I_{\mathrm{ACh}}\right)$ without affecting the $I_{\mathrm{s}}$ and time-dependent outward current $\left(I_{\mathrm{x}}\right)$. In the guinea-pig papillary muscle, however, OCHI and HiNo (1980) demonstrated that ACh depresses both the $I_{\mathrm{s}}$ and $I_{\mathrm{x}}$ without producing $I_{\mathrm{ACh}}$. The discrepancy in these results strongly suggests that effects of ACh vary considerably with animal species and the portion of myocardium involved. In the present experiments on the bullfrog atrium, threshold concentration of $\mathrm{ACh}$ for the negative inotropic effect was about $10^{-9} \mathrm{M}$ (Fig. 1), while that for the appearance of $I_{\mathrm{ACh}}$ was $10^{-7} \mathrm{M}$ (Fig. 5). $\quad \mathrm{p} D_{2}$ value in the dose-tension response curve $\left(7 \times 10^{-8} \mathrm{M}\right)$ was about 30 times lower than that in the dose- $I_{\mathrm{ACh}}$ response curve (compare Fig. 1 with Fig. $5 \mathrm{C}$ ). Our results are in good accord with the observations of GiLEs and NoBLE (1976) and indicate that in the frog myocardium, the negative inotropic effect of $\mathrm{ACh}$ depends mainly on the inhibition of $I_{\mathrm{s}}$.

Under these experimental conditions, further addition of adenosine produced a prolongation of action potential (Fig. 2) and a non-competitive augmentation of the twitch tension (Fig. 1) at low concentrations of $\mathrm{ACh}\left(10^{-9}-10^{-7} \mathrm{M}\right)$. The addition of adenosine, however, depressed the $I_{\mathrm{s}}$ and $I_{\mathrm{ACh}}$ (Fig. 6B, 5C). The depression of these currents would hardly explain the recovery of the twitch tension after adenosine. The remaining possibility is a depression of $I_{\mathrm{x}}$, and we found the $I_{\mathrm{x}}$ to be extremely sensitive to adenosine, even in a concentration of $10^{-5} \mathrm{M}$. Thus, in the frog atrium, a depression of $I_{\mathrm{x}}$ appeared to play a principal role in the prolongation of the action potential by adenosine in the presence of $\mathrm{ACh}$ in low concentrations, although with higher concentrations, depression of $I_{\mathrm{ACh}}$ may participate, in the case of mammalian atrium (TEN EICK et al., 1976). It is noteworthy that adenosine, which may enhance potassium permeability in the sinus node of frog heart (HARTZELL, 1979), strongly inhibits the potassium-related currents in the atrium. 
Possible action of adenosine on cyclic nucleotides. Adenine nucleotides and adenosine evoke various cardiovascular responses, most of which involve changes in endogenous adenosine $3^{\prime}, 5^{\prime}$ cyclic monophosphate (cAMP) and guanosine 3', 5' cyclic monophosphate (cGMP) (see Drummond and SEverson, 1979; BURNSTOCK, 1980). In the isolated frog ventricle, the magnitude of twitch tension correlates with equivalent changes in the ratio of cAMP: cGMP, not only during augmentation of twitch contraction by isoproterenol (SINGH et al., 1978) but also during hypodynamic depression (FLITNEY et al., 1978) and during the action of adenosine and adenine nucleotides (Singh and Flitney, 1980). Since ACh also increases cGMP, a nucleotide which may have regulatory actions antagonistic to those of cAMP in the myocardium (GEORGE et al., 1973; see DRUMMOND and SEVERSON, 1979), the effect of the mode of interaction between ACh and adenosine on the contractile tension, membrane potential and current components should be considered in relation to alterations in the level of cyclic nucleotides.

A possible close relationship between the levels of cAMP and the slow inward current $\left(I_{\mathrm{s}}\right)$ has to be given attention, since intracellular administration of cAMP and application of membrane permeable mono- or di-butyryl cAMP both enhanced the $I_{\mathrm{s}}$, the amplitude of plateau potential or of slow action potential in the partially depolarized myocardium (TSIEN et al., 1972; TSIEN, 1973; REUTER, 1974; SCHNEIDER and SPERELAKIS, 1975). In preceding papers, we clarified the situation that adenosine depresses the $I_{\mathrm{s}}$ and $I_{\mathrm{s}}$-dependent tension, particularly in the case of augmentation by adrenaline or caffeine (Goto et al., 1978, 1979). In the present experiments, adenosine diminished further the depressed $I_{\mathrm{s}}$ and $I_{\mathrm{s}}$-dependent tension due to ACh (Figs. 3, 4). As our observations are in good parallel with the aforementioned principle, an explanation can be made on the bases.

Remaining to be determined are the relationships between cyclic nucleotides and outward currents such as $I_{\mathrm{ACh}}$ and $I_{\mathrm{x}}$, since alteration of these currents did not always cause parallel alterations in $I_{\mathrm{s}}$, and the ACh-dose dependency of these currents differed. Similarly, the $I_{\mathrm{s}}$ and $I_{\mathrm{x}}$ both decreased with application of adenosine in the presence of caffeine, but not in the presence of adrenaline where the $I_{\mathrm{s}}$ was mainly affected (Goтo et al., 1978, 1979). One related factor is the alteration in the intracellular concentration of calcium ions, $[\mathrm{Ca}]_{\mathrm{i}}$ which would have a considerable effect on the potassium-related outward currents (IsENBERG, 1977). Adenosine generally diminishes Ca-fluxes, while caffeine increases these fluxes (GUTHRIE and NAYLER, 1967). We found that adenosine diminished the $I_{\mathrm{s}}$, and $I_{\mathrm{s}}$-dependent and -independent tensions in the presence of $\mathrm{ACh}$, thereby strongly suggesting a decrease of $[\mathrm{Ca}]_{i}$. This decrease of $[\mathrm{Ca}]_{i}$ by adenosine may enhance the inhibition of $I_{\mathrm{x}}$ and the background current more than in the case of being solely due to a decrease in the levels of cAMP (Singh and Flitney, 1980). ACh inhibits the $I_{\mathrm{S}}$ but possibly increases $[\mathrm{Ca}]_{\mathrm{i}}$ since it produces an increase in the potassium-induced contracture and the $I_{\mathrm{s}}$-independent tonic tension (Iкемото and Goто, 1977). 
The authors wish to express their thanks to Mrs. M. Ohara, Kyushu University, for critical readings of this manuscript. This research was supported by Grant-in-Aid for Scientific Research (348092, 548090) from the Ministry of Education, Science and Culture of Japan.

\section{REFERENCES}

Belardinelli, L., Rubio, R., and Berne, R. M. (1979) Blockade of $\mathrm{Ca}^{2+}$ dependent rat atrial slow action potentials by adenosine and lanthanum. Pfü̈gers Arch., 380: 19-27.

Burnstock, G. (1980) Purinergic receptors in the heart. Circ. Res. (Suppl. 1), 46: 175-182.

DiFrancesco, D., Noma, A., and Trautwein, W. (1980) Separation of current induced by potassium accumulation from acetylcholine-induced relaxation current in the rabbit S-A node. Pflügers Arch., 387: 83-90.

Drummond, G. I. and Severson, D. L. (1979) Cyclic nucleotides and cardiac function. Circ. Res., 44: 145-153.

DRURY, A. N. and SzENT-GYÖRGYI (1929) The physiological activity of adenine compounds with especial reference to their action upon the mammalian heart. J. Physiol. (Lond.), 68: 213237.

Flitney, F. W., LAMB, J. F., and Singh, J. (1978) Intracellular cyclic nucleotides and contractility of the hypodynamic frog ventricle. J. Physiol. (Lond.), 276: 38 P-39 P.

GARNIER, D., NARGeOT, J., OJeDA, C., and Rougier, O. (1978) The action of acetylcholine on background conductance in frog atrial trabeculae. J. Physiol. (Lond.), 274: 381-396.

George, W. J., Wilkerson, R. D., and Kadowitz, P. J. (1973) Influence of acetylcholine on contractile force and cyclic nucleotide levels in the isolated perfused rat heart. J. Pharmacol. Exp. Ther., 184: 228-235.

Giles, W. and Noble, S. J. (1976) Changes in membrane currents in bullfrog atrium produced by acetylcholine. J. Physiol. (Lond.), 261: 103-123.

Goto, M., Yatani, A., and Tsuda, Y. (1977) An analysis of the action of ATP and related compounds on membrane current and tension components in bullfrog atrial muscle. Jpn.J. Physiol., 27: 81-94.

Goto, M., YATANI, A., and Tsuda, Y. (1978) Stabilizing effects of adenosine on the membrane currents and tension components of the bullfrog atrium. Jpn. J. Physiol., 28: 611-625.

Goto, M., YATANI, A., and EhARA, T. (1979) Interaction between caffeine and adenosine on the membrane current and tension component in the bullfrog atrial muscle. Jpn. J. Physiol., 29: 393-409.

GUTHRIE, J. R. and NAYLER, W. G. (1967) Interaction between caffeine and adenosine on calcium exchangeability in mammalian atria. Arch. Int. Pharmacodyn. Ther., 170: 249-255.

HARTZeLL, H. C. (1979) Adenosine receptors in frog sinus venosus: Slow inhibitory potentials produced by adenine compounds and acetylcholine. J. Physiol. (Lond.), 293: 23-49.

Hollander, P. B. and WeBB, J. L. (1957) Effects of adenine nucleotides on the contractility and membrane potentials of rat atrium. Circ. Res., 5: 349-353.

HUtTer, O. F. (1961) Ion movements during vagus inhibition of the heart. In: Nervous Inhibition, ed. by Florey, E. Pergamon Press, Oxford, pp. 114-123.

Iкемото, Y. and Goто, M. (1975) Nature of the negative inotropic effect of acetylcholine on the myocardium: An elucidation on the bullfrog atrium. Proc. Jpn. Acad., 51: 501-505.

Iкемото, Y. and Goto, M. (1977) Effects of ACh on slow inward current and tension components of the bullfrog atrium. J. Mol. Cell. Cardiol., 9: 313-326.

IsenBerG, G. (1977) Cardiac Purkinje fibers. Pflügers Arch., 371: 51-59, 61-69, 71-76, 77-85.

Johnson, E. A. and McKinnon, M. G. (1956) Effects of acetylcholine and adenosine on cardiac cellular potentials. Nature, 178: 1174-1175. 
Noma, A., Osterrieder, W., and Trautwein, W. (1979) The effect of external potassium on the elementary conductance of the ACh-induced potassium channel in the sino-atrial node. Pflügers Arch., 381: 263-269.

Noma, A. and Trautwein, W. (1978) Relaxation of the ACh-induced potassium current in the rabbit sinoatrial node. Pflügers Arch., 307: 193-200.

OCHI, R. and HiNo, N. (1980) The effect of acetylcholine on the membrane currents of mammalian ventricular muscle. Proc. IUPS, 19: 617.

REUTER, H. (1974) Localization of beta adrenergic receptors and effects of noradrenaline and cyclic nucleotides on action potentials, ionic currents and tesnion in mammalian cardiac muscle. J. Physiol. (Lond.), 242: 429-451.

Schneider, J. A. and Sperelakis, N. (1975) Slow $\mathrm{Ca}^{2+}$ and $\mathrm{Na}^{+}$responses induced by isoproterenol and methylxanthines in isolated perfused guinea pig hearts exposed to elevated $\mathrm{K}^{+}$. J. Mol. Cell. Cardiol., 7 : 249-273.

Schrader, J., Baumann, G., and Gerlach, E. (1977) Adenosine as inhibitor of myocardial effects of catecholamines. Pflügers Arch., 372: 29-35.

SChrader, J., Rubio, R., and Berne, R. M. (1975) Inhibition of slow action potentials of guinea pig atrial muscle by adenosine: A possible effects on $\mathrm{Ca}^{++}$influx. J. Mol. Cell. Cardiol., 7: 427-433.

Singh, J. and Flitney, F. W. (1980) Adenosine depresses contractility and stimulates 3', 5' cyclic nucleotide metabolism in the isolated frog ventricle. J. Mol. Cell. Cardiol., 12: 285297.

Singh, J., ElitNey, F. W., and LAMB, J. F. (1978) Effects of isoprenaline on contractile force and intracellular cyclic 3, 5 nucleotide levels in the hypodynamic frog ventricle. FEBS Lett., 91 : 269-272.

Ten Eick, R., Nawrath, H., McDonald, T., and Trautwein, W. (1976) On the mechanism of negative inotropic effect of acetylcholine. Pfügers Arch., 361: 207-213.

Trautwein, W., Kuffler, S. W., and Edwards, C. (1956) Changes in membrane characteristics of heart muscle during inhibition. J. Gen. Physiol., 40: 135-145.

TsIEN, R. W. (1973) Adrenaline-like effects of intracellular iontophoresis of cyclic AMP in cardiac Purkinje fibres. Nature (New Biol.), 245: 120-122.

Tsien, R. W., Giles, W., and Greengard. P. (1972) Cyclic AMP mediates the effects of adrenaline on cardiac Purkinje fibers. Nature (New Biol.), 240: 181-183.

YATANI, A., Gото, M., and TsudA, Y. (1978) Nature of catecholamine-like actions of ATP and other energy rich nucleotides on the bullfrog atrial muscle. Jpn. J. Physiol., 28: 47-61.

Vol. 31, No. 4, 1981 